\title{
Южноамериканская томатная моль Tuta absoluta Meyrick - новый опасный вредитель томата в Ростовской области
}

\section{И.М. Митюшев, В.В. Огнев, Е.И. Корсунов}

В статье представлена информация о происхождении и распространении южноамериканской томатной моли Tuta absoluta Meyrick в мире. По состоянию на конец 2019 года, южноамериканская томатная моль распространена в большинстве стран Южной Америки, в Центральной Америке вредитель отмечен в Коста-Рике, Панаме и Гаити. В Африке вредитель отмечен в 25 странах. В Азии южноамериканская томатная моль отмечена в Ираке, Иране, Сирии, Турции, Узбекистане, Киргизии, Таджикистане, Азербайджане, Индии, Бангладеш и Непале. Проникнув впервые в Испанию в 2006 году, T. absoluta к настоящему времени широко распространилась в Европе. В России южноамериканская томатная моль была впервые выявлена в 2010 году в республике Адыгея. Дано описание морфологических и биологических особенностей вредителя. Показано распространение и вредоносность томатной моли в Ростовской области РФ. В 2019 году томатная моль распространилась по всей территории станицы Кривянская. Первые признаки повреждения томатов молью в 2019 году отмечали уже с июня, лишь на некоторых отдаленных фермерских участках - с июля. Первые очаги в теплицах отмечаются, как правило, на боковых рядах и в углах теплиц. Предложены меры борьбы с вредителем для сдерживания его распространения. Необходим тщательный карантинный контроль продукции и рассады пасленовых культур из зон распространения вредителя, обеспечение пространственной изоляции теплиц от посадок пасленовых культур открытого грунта. Необходимо регулярно уничтожать поврежденные части растений (листьев с минами, плодов с ходами), послеуборочных остатков и пасленовых сорняков. Следует соблюдать плодосмен с выращиванием неповреждаемых промежуточных культур. В течение вегетации необходимо выявлять вредителя и проводить массовый вылов самцов с использованием феромонных ловушек. Международный комитет по предотвращению развития резистентности к инсектицидам рекомендует к применению против T. absoluta порядка 40 препаратов из 12 классов, включая бактериальные.

Ключевые слова: томат, южноамериканская томатная моль, Tuta absoluta, выемчатокрылые моли, Gelechiidae, карантин растений, защита растений, идентификация вредителя, вредоносность, меры борьбы.

Ю жноамериканская матная моль absoluta Meyrick Чешуекрылые (Lepidoptera), семейство Выемчатокрылых молей (Gelechiidae) - опасный вредитель томата и других пасленовых культур. Естественный ареал томатной моли охватывает территорию Перу, откуда она распространилась во многие страны Южной и Центральной Америки, Африки, Европы и Азии [1, 2]. Распространение южноамериканской томатной моли в мире происходило в основном с импортируе- и южную часть континента. В Азии южноамериканская томатная моль отмечена в Ираке, Иране, Сирии, Турции, Узбекистане, Киргизии, Таджикистане, Азербайджане, Индии, Бангладеш и Непале. Проникнув впервые в Испанию в 2006 году, T. absoluta к настоящему времени широко распространилась в Европе: сейчас она отмечена в Албании, Австрии, Беларуси, Бельгии, Боснии и Герцеговине, Болгарии, Хорватии, Кипре, Чехии, Дании, Франции, Германии, Греции, острове Гернси, Венгрии, Италии, Литве, Черногории, Нидерландах, Северной Македонии, Норвегии, Португалии, Румынии, Сербии, Словении, Испании, Швейцарии, Украине, Великобритании [4]. На территории России южноамериканская томатная моль была впервые выявлена в 2010 году в республике Адыгея [3]. Этот вредитель включен в Единый перечень карантинных объектов Евразийского экономического союза, вступивший в силу с 1 июля 2017 года [5]. На этом основании Федеральная служба по ветеринарному и фитосанитарному надзору (Россельхознадзор) применяет карантинные фитосанитарные меры в отношении подкарантинной продукции, зараженной указанным карантинным объектом, и к территориям, где обнаружены его очаги. По официальным данным Россельхознадзора, по состоянию на 1 января 2019 года на территории Российской Федерации очаги южноамериканской томатной моли выявлены на общей площади 723,37 га, в шести субъектах Российской Федерации [6].

Морфология и идентификация. Яйца мелкие, цилиндрические, 0,36×0,22 мм, беловатые или желтоватые. Гусеницы имеют 16 ног, с темной головой, беловатые, 0,5 мм в длину в I возрасте, начиная со II воз- 


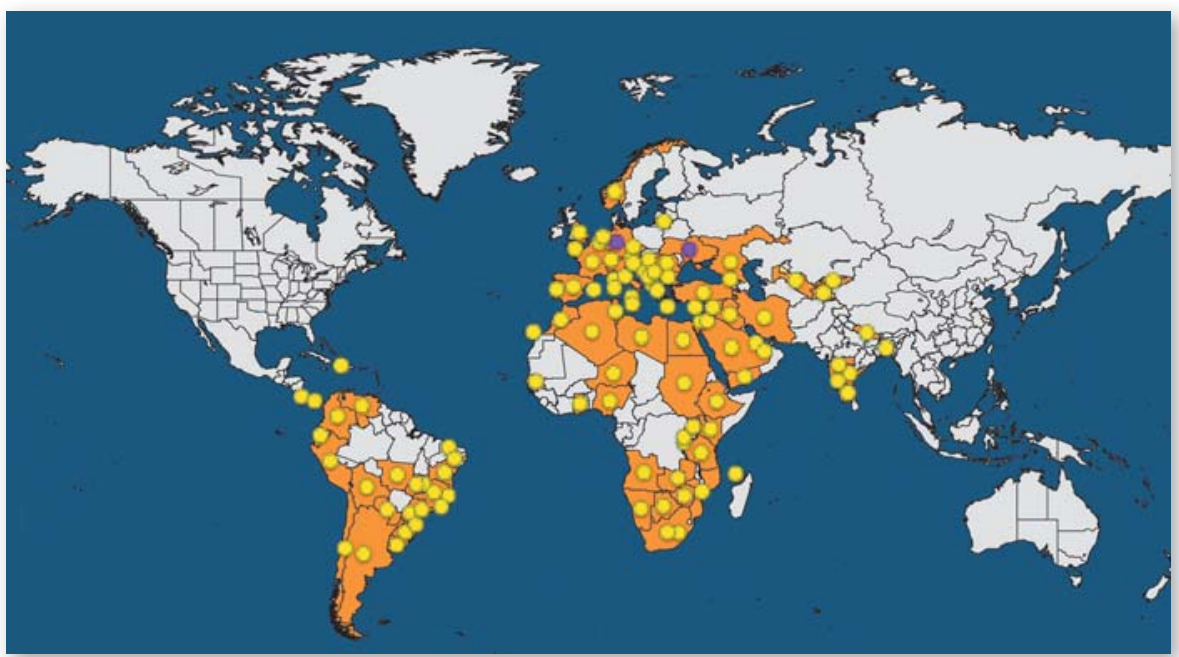

Рис. 1. Географическое распространение южноамериканской томатной моли [4]

раста - зеленоватые или розоватые, достигают в длину 7,5 мм в IV возрасте. Куколка покрытая, коричневая, 6 мм в длину. Тело моли серое, длиной 5-7 мм, размах крыльев 10-12 мм. Антенны нитевидные, черные со светло-серыми кольцами. Передние крылья серые, с рыжевато-бурой и белой крапчатостью и черноватыми пятнами, окаймленными рыжеватобурым или желтым. Задние крылья темно-серые, более светлые к основанию, с выемкой перед вершиной, как и у других представителей семейства Выемчатокрылых молей [7]. Внешне сходный вид - картофельная моль Phthorimaea operculella Zeller (Lepidoptera: Gelechiidae), также включенная в Единый перечень карантинных объектов Евразийского экономического союза и ограниченно распространенная на юге России; T. absoluta отличается от нее меньшими размерами (размах крыльев у Ph. operculella составляет 12-17 мм) и более узкими передними крыльями с преобладанием серого цвета (рис. 2). Точная видовая идентификация насекомых возможна только на основе препаратов гениталий самцов и должна осуществляться квалифицированным энтомологом в лабораторных условиях [2, 3].

Биология и вредоносность. Южноамериканская томатная моль наиболее сильно повреждает томаты как в закрытом, так и в открытом грунте; также повреждает картофель, баклажаны, физалис и перец, другие виды пасленовых. В открытом грунте вредитель может зимовать в стадии яйца, куколки или имаго; в теплицах развитие идет круглый год, без диапаузы. Самки откладывают яйца на верхнюю сторону молодых листьев или на стебли, их плодовитость 50350 яиц, эмбриональное развитие продолжается 3-8 дней. Личиночное развитие, в зависимости от температуры воздуха,продолжается 10-30 Рис. 2. Имаго томатной моли (фото Marja van der дней. Гусеницы питаются внут- Straten, National Reference Centre, Plant Protection Service, Wageningen) $10{ }^{\circ} \mathrm{C}$, продолжительность развития одного поколения в теплицах - 20-40 дней. В условиях защищенного грунта может развиваться 10-12 поколений вредителя за год [1, 2, 3, 8].

Цель исследований - изучить распространение томатной моли в Ростовской области и предложить меры борьбы с ней и мероприятия по ограни-

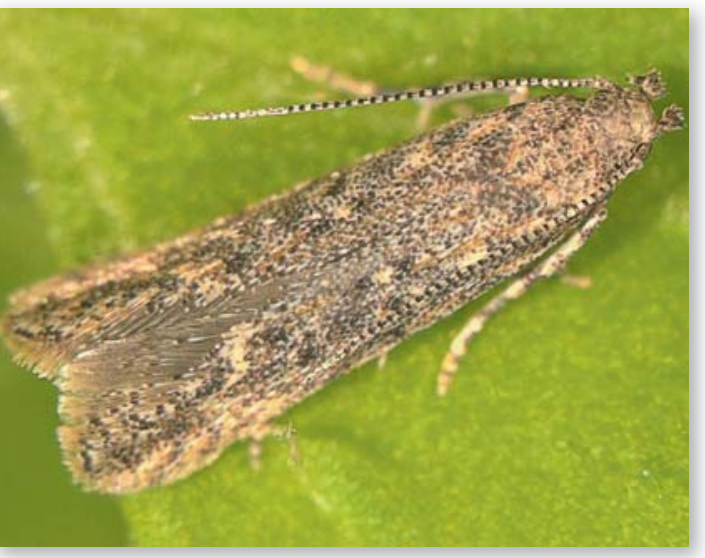

\begin{tabular}{|c|c|c|c|c|c|}
\hline $\begin{array}{c}\text { Торговое название } \\
\text { препарата, } \\
\text { концентрация, } \\
\text { классы опасности }\end{array}$ & $\begin{array}{c}\text { Действующее } \\
\text { вещество }\end{array}$ & $\begin{array}{l}\text { Норма расхода } \\
\text { препарата, л/га }\end{array}$ & $\begin{array}{l}\text { Технология } \\
\text { применения }\end{array}$ & $\begin{array}{c}\text { Срок ожидания, } \\
\text { дни (кратность } \\
\text { обработок) }\end{array}$ & $\begin{array}{l}\text { Срок выхода для } \\
\text { ручных работ, дни }\end{array}$ \\
\hline $\begin{array}{l}\text { Флекси, СК } \\
\text { (200 + } 100 \text { г/л) } \\
3 / 1\end{array}$ & $\begin{array}{l}\text { Тиаметоксам +хло- } \\
\text { рантранилипрол }\end{array}$ & $0,3-0,4$ & $\begin{array}{l}\text { Опрыскивание в } \\
\text { период вегетации. } \\
\text { Расход рабочей жид- } \\
\text { кости - 1000-3000 } \\
\text { л/га }\end{array}$ & $5(1)$ & 2 \\
\hline $\begin{array}{l}\text { Беневия, МД } \\
(100 \text { г/л) } \\
3 / 3\end{array}$ & Циантранилипрол & 0,5 & $\begin{array}{l}\text { Опрыскивание в } \\
\text { период вегетации. } \\
\text { Интервал между } \\
\text { обработками 10-14 } \\
\text { дней. Расход рабочей } \\
\text { жидкости -500-1000 } \\
\text { л/га }\end{array}$ & $1(4)$ & 1 \\
\hline
\end{tabular}

ри листовой пластинки, выедая паренхиму и образуя двусторонние мины с центральной камерой и отходящими от нее извилистыми ходами, затем приводящие к усыханию листовой пластинки (рис. 3); внутри стеблей проделывают ходы. Нередко гусеницы покидают листовые мины, прогрызая эпидермис, и проникают в другие листья или плоды. В плодах томата, перца и баклажана личинки также проделывают извилистые ходы, что приводит к загниванию плодов и снижению их потребительских качеств и лежкости (рис. 4). Поврежденные листья и плоды быстро поражаются фитопатогенами. После окончания питания гусеницы окукливаются в шелковистом коконе на кормовых растениях, растительных остатках или в почве, стадия куколки продолжается 6-20 дней. Нижний порог развития вредителя -

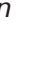




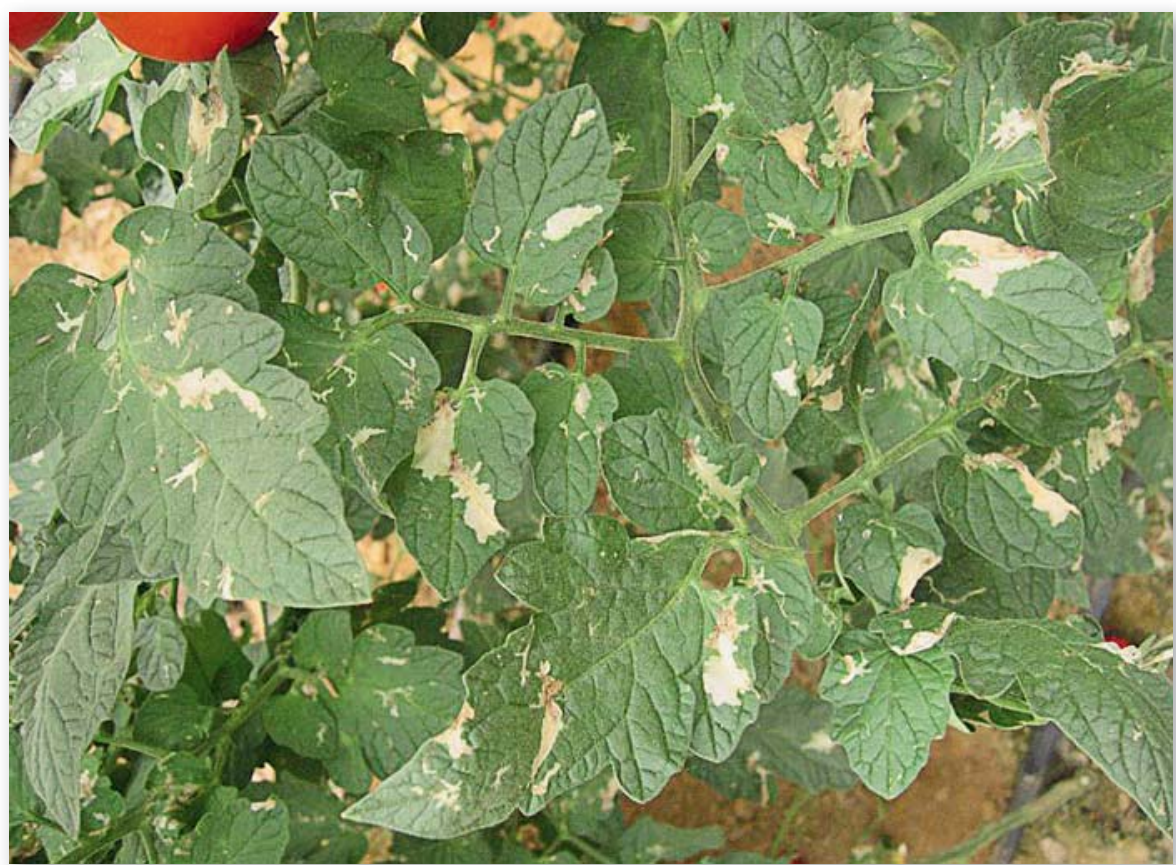

Рис. 3. Мины томатной моли на листьях томата (фото Dr Andrea Minuto, CERSAA, Albenga)

чению распространения вредителя из очага, сформировавшегося в станице Кривянской Ростовской области РФ.

Результаты исследований. Особенности развития и вредоносности южноамериканской томатной моли в станице Кривянская Ростовской области изучали с момента обнаружения вредителя в 2018 году. В 2018-2019 года были опробованы различные способы защиты от вредителя и оценена их эффективность. Предложены товаропроизводителям меры по предотвращению распространения томатной

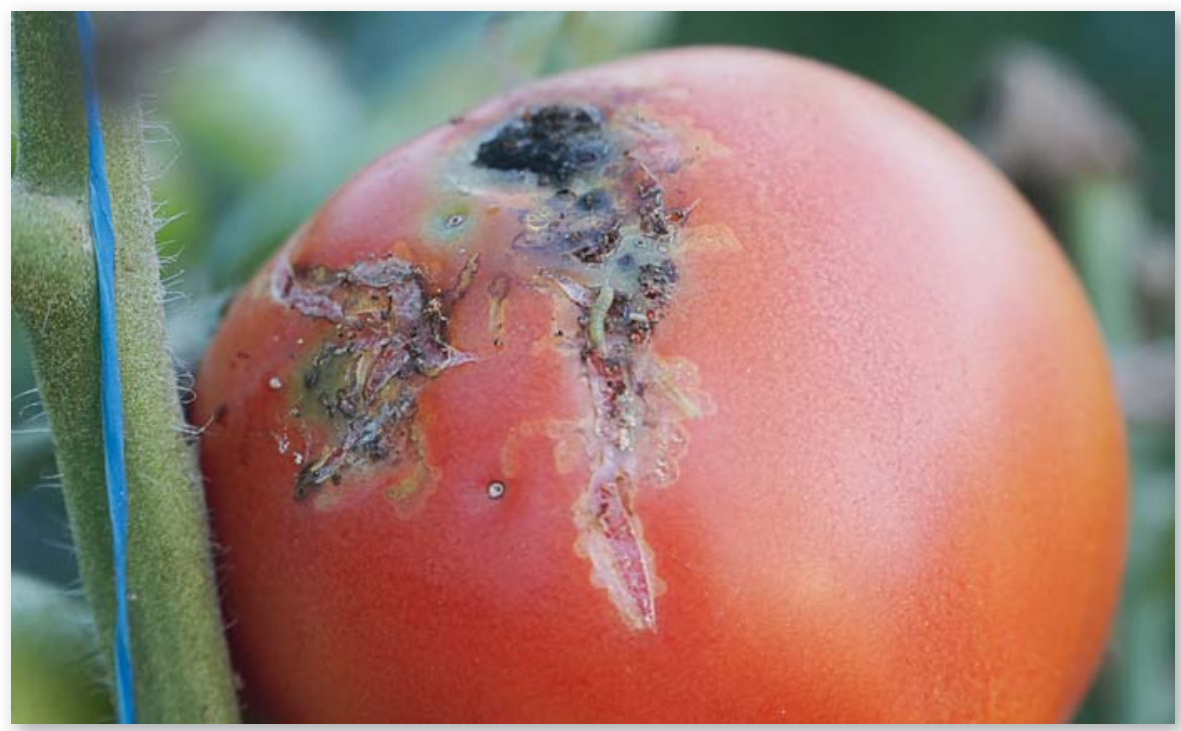

Рис. 4. Плоды, поврежденные томатной молью (фото Е.И. Корсунова) грузку томатов для транспортировки в центральный регион России, и именно на этот склад вредитель был завезен транспортными средствами. Уже в 2019 году томатная моль распространилась по всей территории станицы Кривянская. Первые признаки повреждения томатов молью в 2019 году отмечали уже с июня, лишь на некоторых отдаленных фермерских участках - с июля. Первые очаги в теплицах отмечаются, как правило, на боковых рядах и в углах теплиц. На молодых листьях появляются мины, в дальнейшем происходит частичное или полное повреждение листьев вредителем в сочетании с развитием грибных заболеваний. Также личинки повреждают растущие побеги и в дальнейшем проникают внутрь стебля растения. Повреждение плодов личинками $T$. absoluta происходило с момента их появления на всех фенофазах. Массовое распространение вредителя происходило в течение 2-3 недель. Урожайность второго оборота томатов в 2019 году снизилась на 30\%, качество урожая - на 70\%. В условиях теплиц станицы Кривянская, T. absoluta повреждает все гибриды томатов, наименьшие повреждения наблюдаются на томатах-черри. Фермеры применяли широкий ассортимент инсектицидов с повышенными нормами расхода, в том числе, через систему капельного орошения. Также применяли феромонные и светоловушки, дымные шашки. Применявшиеся меры обеспечивали только временное снижение численности вредителя в теплицах, через 2-5 дней его численность вновь возрастала. Действенным методом стало использование противомоскитных сеток на вентиляции и защитных тамбуров на входах в теплицы, предотвращавших проникновение имаго моли в них, в сочетании с профилактическими обработками инсектицидами не только внутри, но и с наружи культивационных сооружений и применение биопрепаратов в поздние фазы, удаление сорной растительности на всей территории выращивания томата.

На сегодняшний день необходим тщательный карантинный контроль продукции и рассады пасленовых культур из зон распространения вредителя. Обеспечение пространственной изоляции теплиц от посадок пасленовых культур открытого грунта. Необходимо регулярно уничтожать поврежденные части растений (листьев с минами, плодов с ходами), послеуборочных остатков и пасленовых сорняков. Следует соблюдать плодосмен с выращиванием неповреждае- 
мых промежуточных культур. В течение вегетации необходимо выявлять вредителя и проводить массовый вылов самцов с использованием феромонных ловушек. Для мониторинга водные феромонные ловушки размещают в теплицах из расчета 1 ловуш-

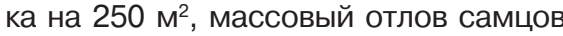
вредителя возможен при размещении

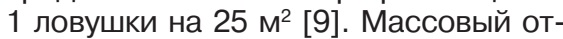
лов бабочек томатной моли можно также проводить при помощи желтых цветоловушек: их размещают из расчета 20-40 ловушек/га [10].

Опыт применения инсектицидов против томатной моли в других странах показал, что их интенсивное применение приводит к развитию резистентности у вредителя. Это приводит к необходимости постоянного чередования препаратов и увеличения норм их расхода. Международный комитет по предотвращению развития резистентности к инсектицидам рекомендует к применению против T. absoluta порядка 40 препаратов из 12 классов, включая бактериальные биопрепараты на основе Bacillus thuringiensis, синтетические пиретроиды (бифентрин, циперметрин, дельтаметрин и др.), фосфорорганические препараты (хлорпирифос, метамидофос), регуляторы роста и развития (дифлубензурон, люфенурон и др.) и др.

В «Государственный каталог пестицидов и агрохимикатов, разрешенных к применению на территории Российской Федерации» сегодня включены только два инсектицида, рекомендуемых для защиты томата защищенного грунта от T. absoluta (табл.). При этом препарат Флекси, СК - бинарный, в его состав входит неоникотиноид (тиаметоксам) и рионоид (хлорантранилипрол), данный препарат высокопасен для пчел, допускается его однократное применение в течение вегетации. Препарат Беневия, МД - однокомпонентный, действующее вещество - циантранилипрол из класса рионоиды. Он малоопасен для пчел, разрешено проводить до четырех опрыскиваний в течение вегетации.

Перспективно применение против южноамериканской томатной моли агентов биологической борьбы [12]. Так, за рубежом эффективно применяют хищного клопа макролофуса Macrolophus pygmaeus Rambur (Hemiptera: Miridae). Выпуск макролофуса проводят 4-5 раз, с интервалами в две недели, по 2-4 особи/м². Используют и других агентов биологической борьбы, например, многоядного хищного клопа незидокорис Nesidiocoris tenuis Reuter (Hemiptera: Miridae) и яйцевых наездников трихограмм Trichogramma spp.
(Hymenoptera: Trichogrammatidae) [12].

Таким образом, по состоянию на конец 2019 года южноамериканская томатная моль зарегистрирована в Ростовской области. Эффективный контроль вредителя требует комплексного подхода, который включает карантинные, организационные, профилактические мероприятия, включает агротехнический, химический, биологический методы защиты.

\section{Библиографический список}

1.Datasheet: Tuta absoluta (tomato leafminer) [Электронный ресурc]. URL: https://www.cabi.org/isc/ datasheet/49260. Дата обращения: 28.10.2019

2.Жимерикин В.Н., Миронова М.К., Дулов М.В. Южноамериканская томатная моль // Защита и карантин растений. 2009. № 6. С. 34-35.

3.Ижевский С.С., Ахатов А.К., Синев С.Ю. Томатная минирующая моль выявлена уже в России // Защита и карантин растений. 2011. № 3. С. 40-44.

4.Tuta absoluta // EPPO Global Database. [Электронный pecypc].URL: https://gd.eppo.int/taxon/GNORAB. Дата обращения: 28.10.2019.

5.Единый перечень карантинных объектов Евразийского экономического союза с изменениями и дополнениями от 2 мая 2018 г. [Электронный ресурс]. URL: $\quad$ https://vniikr.ru/edinyij-perechen-karantinnyixobektov-evrazijskogo-ekonomicheskogo-soyuza. Дата обращения: 28.10.2019.

6.Национальный доклад о карантинном фитосанитарном состоянии территории Российской Федерации. [Электронный ресурс]. URL: https://www.fsvps.ru/ fsvps-docs/ru/usefulinf/files/nd2019.pdf. Дата обращения: 28.10.2019.

7.Захваткин Ю.А., Митюшев И.М., Третьяков Н.Н. Биология насекомых: учебное пособие. М.: Книжный дом «Либроком» / URSS, 2013. 392 с.

8.Защита растений: фитопатология и энтомология: учебник. / О.О. Белошапкина, В.В. Гриценко, И.М. Митюшев, Чебаненко С.И. Ростов-на-Дону: Феникс, 2017. 477 с.

9.Митюшев И.М. Феромоны насекомых и их применение в защите растений: Учебное пособие. М.: Изд-во РГАУ-МСХА имени К.А. Тимирязева, 2015. 124 с.

10.Равашдех Ш.Х.А.-А. Биология, вредоносность и совершенствование мер борьбы против томатной моли - Tuta absoluta (Meyrick) - в условиях Иордании: автореф. дис. на соиск. учен. степ. канд. биол. наук: М.: РГАУ-МСХА имени К.А. Тимирязева, 2014. 23 c.

11.Государственный каталог пестицидов и агрохимикатов, разрешенных к применению на территории Российской Федерации. Часть І. Пестициды. Издание официальное. М., Минсельхоз России. 2019. 861 с. [Электронный ресурc]. URL: http://www.mcx.ru. Дата обращения: 28.10.2019.

12.Прищепа Л.И., Войтка Д.В. Биологической контроль томатной минирующей моли // Защита и карантин растений. 2013. № 4. С. 39-42.

\section{Об авторах}

Митюшев Илья Михайлович, канд. биол. наук, доцент кафедры защиты растений, ФГБОУ ВО РГАУ-МСХА имени К.А. Тимирязева.

E-mail: mityushev@mail.ru

\section{Огнев Валерий Владимирович,}

канд. с.-х. наук, доцент, директор

ССЦ «Ростовский» Агрохолдинга

«Поиск». E-mail: ognevvv@bk.ru

Корсунов Евгений Иванович, аспирант, ФГБОУ ВО ДОНСКОЙ ГАУ.

E-mail: bes-i993@mail.ru
The South American tomato moth, Tuta absoluta Meyrick, is a new dangerous pest of tomato in the Rostov region of Russia

I.M. Mityushev, PhD, associate professor, Department of Plant protection, Russian

State Agrarian University - Moscow

Timiryazev Agricultural Academy.

E-mail:mityushev@mail.ru

V.V. Ognev, PhD, associate professor,

director, Rostov Breeding Centre of

PoiskAgro Holding. E-mail:ognevvv@bk.ru

E.I. Korsunov, postgraduate student, Don

State Agrarian University.

E-mail: bes-i993@mail.ru

Summary. The article deals with data on origin and world distribution of the South American tomato moth, Tuta absoluta Meyrick. At the end of 2019, the South American tomato moth is common pest in most of South America, in Central America, it is noted in Costa Rica, Panama and Haiti. In Africa, the pest has been recorded in 25 countries. In Asia, the South American tomato moth has been recorded in Iraq, Iran, Syria, Turkey, Uzbekistan, Kyrgyzstan, Tajikistan, Azerbaijan, India, Bangladesh and Nepal. Having first penetrated Spain in 2006, T. absoluta has now spread widely in Europe. In Russia, the South American tomato moth was first identified in 2010 in the Republic of Adygea. The description of morphological and biological features of the pest is given. The distribution and harmfulness of tomato moth under conditions of the Rostov Oblast of Russia is shown. In 2019, the tomato moth spread throughout the Krivyanskaya village. The first signs of damage to tomatoes by moths in 2019 have been noted since June, only in some remote farm areas - since July. The first foci in greenhouses are noted, as a rule, on the side rows and in the corners of greenhouses. The pest control measures to limit its further spreading are suggested. A thorough quarantine control of products and seedlings of nightshade crops from the pest distribution zones is necessary, ensuring the spatial isolation of greenhouses from planting nightshade crops in the open ground. It is necessary to destroy damaged parts of plants (leaves with mines, fruits with moves), post-harvest residues and nightshade weeds regularly. It is necessary crop rotation with the growing of intact intermediate crops. During the growing season, it is necessary to identify the pest and conduct a mass catch of males using pheromone traps. The international Committee for the prevention of insecticide resistance recommends the use of about 40 preparations from 12 classes, including bacterial, against $T$. absoluta.

Keywords: tomato, South American tomato moth, Tuta absoluta, gelechiid moths, Gelechiidae, plant quarantine, plant protection, pest identification, harmfulness, pest control. 